\title{
Influences of native and non-native benthivorous fishes on aquatic ecosystem degradation
}

\author{
Jesse R. Fischer • Rebecca M. Krogman • \\ Michael C. Quist
}

Received: 2 May 2012/Revised: 21 February 2013/ Accepted: 23 February 2013/Published online: 14 March 2013

(C) Springer Science+Business Media Dordrecht (outside the USA) 2013

\begin{abstract}
Invasive common carp Cyprinus carpio has long been identified as a contributor to water quality deterioration, disrupted ecosystem processes, and shifts in biological assemblage structure. In contrast, little information is available regarding the effects of native benthivorous species on aquatic systems despite their functional similarity to common carp. Effects of common carp and the native black bullhead Ameiurus melas on sediment resuspension, nutrient concentrations, macrophytes, and assemblage structure of zooplankton and macroinvertebrates, were experimentally evaluated. We observed decreased water clarity, increased nutrient concentrations, decreased macrophyte biomass, and decreased benthic macroinvertebrate abundance and biomass associated with common carp, regardless of the presence of
\end{abstract}

Handling editor: Katya E. Kovalenko

J. R. Fischer ( $\square)$

Department of Natural Resource Ecology and

Management, Iowa State University, Ames,

IA 50011, USA

e-mail: fischer@iastate.edu

R. M. Krogman

Fisheries Division Sacramento, California Department of Fish and Game, Sacramento, CA 95811, USA

M. C. Quist

U.S. Geological Survey, Idaho Cooperative Fish and Wildlife Research Unit, Department of Fish and Wildlife Sciences, University of Idaho, Moscow, ID 83844, USA black bullhead. In contrast, black bullhead increased total phosphorus, and chlorophyll $a$ concentrations and copepod abundance, but had little or no effect on other measured water quality and biological variables when compared to control conditions. Overall, experimental results suggest that although black bullhead tend to be tolerant of degraded ecosystems, they are not a source of physical changes to the environment known to be responsible for perpetuating degraded water quality (e.g., stable state shifts). Therefore, increased abundance of native species, such as black bullhead, following the invasion of common carp, may serve as an indicator of ecological conditions and should not to be assumed as causative.

Keywords Aquatic macrophytes .

Benthic macroinvertebrates - Black bullhead . Common carp - Water quality

\section{Introduction}

Common carp Cyprinus carpio is one of the most widely introduced aquatic species worldwide and has long been associated with physical, chemical, and biological alterations to aquatic systems (Cahn, 1929; reviewed by Weber \& Brown, 2009; Kulhanek et al., 2011; Wahl et al., 2011). Because of their feeding behavior, high fecundity, long lifespan, lack of naturally occurring predators, and ability to exploit regularly disturbed habitats (e.g., those experiencing 
winter hypoxia), invasive common carp have been linked to severe disruptions to shallow freshwater systems (Zambrano et al., 2001; Bajer \& Sorensen, 2010; Jackson et al., 2010). Specifically, common carp resuspend sediments and associated nutrients in the water column by directly feeding on or uprooting macrophytes while foraging for benthic invertebrates (King \& Hunt, 1967; Miller \& Crowl, 2006; Matsuzaki et al., 2009). These activities may create a positive feedback as unconsolidated sediments are more susceptible to resuspension by natural forces, such as wind. Furthermore, nutrients bound to sediments often become available after resuspension, stimulating algal blooms and further decreasing water clarity and the re-establishment of macrophytes. Direct effects of common carp, such as decreased water clarity, increased nutrients, reduced macrophytes, and destabilized substrate, collectively result in shifts of physiochemical states (i.e., clear, macrophyte-dominated vs. turbid, plankton-dominated: Scheffer et al., 1993) of shallow aquatic ecosystems that result in conditions that are often difficult or impossible to restore (Zambrano \& Hinojosa, 1999; Zambrano et al., 2001). For instance, Schrage \& Downing (2004) reported a rapid shift in water clarity of Ventura Marsh, Iowa, USA after a 75\% reduction in common carp abundance. However, after the re-establishment of juvenile common carp, the system quickly reverted to a turbid-water state. In addition to changes in physical habitat, invasion of common carp has also been associated with shifts in biological assemblage structure. Lakes with high biomass of common carp typically contain fewer sight-feeding fish species, while benthic, non-sight feeding, omnivorous, and tolerant species generally increase in abundance (Breukelaar et al., 1994; Jackson et al., 2010). As a result, native species that persist in the presence of common carp often become associated with degraded conditions and are assumed to contribute to environmental deterioration (e.g., Egertson \& Downing, 2004; Schrage \& Downing, 2004).

Common carp-induced shifts in fish assemblages to benthivore-dominated assemblages have spurred research focused on evaluating the relative ecosystem effects of native species that are functionally similar (e.g., trophic guild, habitat-use). In experimental mesocosm studies comparing a native species to common carp, Cline et al. (1994) observed that brown bullhead Ameiurus nebulosus did not increase turbidity and Parkos et al. (2003) reported that channel catfish Ictalurus punctatus had no effect on turbidity, suspended solids, or macrophytes. A reduction in chironomid densities in the presence of juvenile common carp (3-4 cm) was observed by Batzer (1998), whereas adult and juvenile brown bullhead had no effect on macroinvertebrates in ponds of western New York, USA. Similarly, common carp decreased annelid, chironomid, and odonate biomass in experimental mesocosms, while Parkos et al. (2003) did not observe changes in macroinvertebrate abundance for channel catfish compared to control conditions. Although black bullhead Ameiurus melas is taxonomically and functionally similar to common carp, little research has been conducted on its influence on conditions in aquatic ecosystems. Unlike brown bullhead and channel catfish which are less tolerant, black bullhead is generally considered tolerant of a wide range of environmental conditions (Brown et al., 1999; Hanchin et al., 2002a). Black bullhead is also able to sustain high population biomasses (Carlander \& Moorman, 1956) and is ubiquitous across North America (Lee et al., 1980). Consequently, black bullhead is often considered an ecological equivalent to common carp (Egertson \& Downing, 2004; Schrage \& Downing, 2004). In addition, high abundance of black bullhead is often associated with that of common carp (Brown et al., 1999) when the assemblage is not completely dominated by the invasive common carp (Egertson \& Downing, 2004). Because of this association with deteriorated ecological conditions and common carp, black bullhead has been a target of removal efforts in attempts to improve quality of lake ecosystems (Shapiro \& Wright, 1984; Schrage \& Downing, 2004). However, in the only study, we are aware of, that has evaluated the influence of black bullhead on aquatic ecosystems, Braig and Johnson (2003) experimentally tested the effects of adult and juvenile black bullhead density on turbidity in a shallow wetland of Ohio, USA. Although the authors found that black bullhead significantly increased turbidity over fishless control conditions, turbidity in black bullhead enclosures at high biomass (i.e., up to $2,438 \mathrm{~kg} \mathrm{ha}^{-1}$ ) was consistently less than measurements obtained from outside the enclosures where high turbidity was attributed to wind resuspension (Braig \& Johnson, 2003). Therefore, further research is necessary to determine whether management efforts 
that target native benthivores for removal are warranted or are simply the result of assumed functional similarities with invasive common carp.

The management and restoration of aquatic ecosystems is dependent on understanding how benthivorous fishes interact with water quality conditions. Although benthivorous fish species may often occur together at high abundance, few studies have experimentally evaluated the influence of multiple benthivorous species commonly found in North America on water quality conditions. Moreover, most research on the effects of common carp (i.e., field observations, single-species experiments) has focused on a small subset of environmental factors (e.g., turbidity) or native species not commonly associated with degraded conditions like black bullhead (e.g., channel catfish: Parkos et al., 2003). The objective of our study was to identify and quantify the relative ecological impacts of black bullhead on aquatic ecosystem characteristics known to be altered by common carp invasion. We designed a mesocosm experiment to examine the effects of both common carp and black bullhead on water clarity, nutrient concentrations [total phosphorus (TP), nitrate $\left(\mathrm{NO}_{3}{ }^{-}\right)$, nitrite $\left(\mathrm{NO}_{2}{ }^{-}\right)$, ionized ammonia $\left(\mathrm{NH}_{4}{ }^{+}\right)$], submerged macrophyte biomass, zooplankton density, and macroinvertebrate abundance and biomass. Based on the limited information available of black bullhead effects on turbidity (Braig \& Johnson, 2003) and those of species with similar feeding morphology and habits (Siluriformes: Cline et al., 1994; Batzer, 1998; Parkos et al., 2003), we hypothesized that black bullhead would have reduced, if any, impacts on water clarity and associated nutrient concentrations relative to common carp.

\section{Methods}

\section{Experimental mesocosms}

During the summer of 2009, 16 experimental mesocosms were constructed at the Iowa State University Horticulture Research Station $\left(42^{\circ} 6^{\prime} 41^{\prime \prime} \mathrm{N}\right.$, $93^{\circ} 35^{\prime} 2^{\prime \prime} \mathrm{W}$ ) located in central Iowa, USA. Mesocosm size and dimensions $(1.2-\mathrm{m}$ height $\times 1.8$-m diameter $)$ were selected to eliminate the influence of wind resuspension on sediments and associated nutrients. Each mesocosm was filled with approximately $20 \mathrm{~cm}$ of littoral sediment, planted with 20 stems of floating-leaf pondweed Potamogeton natans and $0.5 \mathrm{~m}^{2}$ of coontail Ceratophyllum demersum, and filled with water from a nearby 5-ha lake on 19 June 2009. Mesocosms were allowed to establish for 28 days and randomly assigned to one of four treatments on 16 July 2009. Treatments included stockings of no fish (i.e., control) and equal total biomasses (i.e., approximately $1,000 \mathrm{~g}$ ) of adult common carp, adult black bullhead, and the combination of both species (i.e., approximately $500 \mathrm{~g}$ each). Each treatment was replicated four times. Common carp were collected from Ventura Marsh, Ventura, Iowa, USA $\left(43^{\circ} 7^{\prime} 10^{\prime \prime} \mathrm{N}, 93^{\circ} 30^{\prime} 40^{\prime \prime} \mathrm{W}\right)$ and black bullhead were collected from sediment retention wetlands of Ada Hayden Lake, Ames, Iowa, USA $\left(42^{\circ} 3^{\prime} 45^{\prime \prime} \mathrm{N}, 93^{\circ} 37^{\prime} 55^{\prime \prime} \mathrm{W}\right)$. Common carp and black bullhead used in this study were $357.8 \pm 5.6$ (mean $\pm \mathrm{SE}$ ) and $187.3 \pm 3.5 \mathrm{~mm}$ in total length (TL) and $554.8 \pm 22.4$ and $76.8 \pm 5.4 \mathrm{~g}$ in weight, respectively. Fishes were randomly assigned to treatments until the approximate biomass (i.e., 500 or $1,000 \mathrm{~g}$ ) was obtained for each species. Mean total fish biomass stocked in mesocosms was 1,075.9 $\pm 19.8 \mathrm{~g}$ $\left(4,098.0 \pm 75.3 \mathrm{~kg} \mathrm{ha}^{-1}\right)$.

The experiment persisted for 35 days after stocking fish. The duration of the experiment was based on the time that effects of benthivorous fish were observed in a comparable study (Parkos et al., 2003). Water and zooplankton were sampled two to three times weekly from the week prior to fish stocking until the end of the experiment (20 August 2009). Subsurface 1-L water samples were collected from each mesocosm two to three times weekly to measure turbidity (nephelometric turbidity units; NTUs) and concentrations $(\mu \mathrm{g} / \mathrm{L})$ of chlorophyll $a$ (chl-a), TP, $\mathrm{NO}_{3}{ }^{-}, \mathrm{NO}_{2}{ }^{-}$, and $\mathrm{NH}_{4}{ }^{+}$. Water samples were stored on ice in opaque containers and transported to the laboratory for analysis within $1 \mathrm{~h}$ of collection. Analyses of TP, $\mathrm{NO}_{3}{ }^{-}, \mathrm{NO}_{2}{ }^{-}$, and, $\mathrm{NH}_{4}{ }^{+}$concentrations were conducted using a $\mathrm{HACH}$ DR/3000 spectrophotometer (HACH Company, Loveland, CO, USA) and standard water analysis methods (APHA, 2005). Turbidity was measured with a HACH 2100P turbidimeter (HACH Company, Loveland, CO, USA). A subsample of $200 \mathrm{ml}$ was filtered through a 0.7- $\mu \mathrm{m}$ Whatman GF/F filter (Whatman International, Maidstone, UK). Chlorophyll was extracted with $90 \%$ acetone solution and absorbance was read using an Agilent 8453 spectrophotometer (Agilent Technologies, Inc. Santa Clara, CA, USA) to determine 
chl- $a$ concentrations. Zooplankton samples were collected weekly using a vertically integrated PVC tube sampler (diameter $5 \mathrm{~cm}$, length $80 \mathrm{~cm}$ ), filtered through $80-\mu \mathrm{m}$ mesh, and preserved in $95 \%$ ethanol. Zooplankton were identified to family for Arthropoda (i.e., Crustacea, Diptera) and to phylum for Rotifera. Benthic macroinvertebrates were sampled with an Ekman dredge (area $225 \mathrm{~cm}^{2}$ ) prior to fish stocking and on the last day of the experiment. For both sampling events, a single benthic macroinvertebrate sample was taken from each mesocosm and washed through a $500-\mu \mathrm{m}$ mesh sieve. Samples were preserved in a $10 \%$ formalin solution and identified in the laboratory to the lowest practical taxon which was typically family or order. Terrestrial invertebrates were grouped separately from aquatic invertebrates and removed from further analyses. Benthic invertebrate biomass was estimated using ash-free dry mass. Samples were dried for $24 \mathrm{~h}$ at $60^{\circ} \mathrm{C}$ and ashed for $4 \mathrm{~h}$ at $500^{\circ} \mathrm{C}$. Individual taxa and mesocosms were processed separately. After completion of the experiment, macrophytes were collected from each mesocosm. The wet weight of macrophytes was determined for each species and morphological structure (i.e., stems and leaves, roots) for each mesocosm by clipping stems and leaf biomass and sieving root biomass from the substrate.

\section{Statistical analysis}

Repeated measures (RM) analysis of variance (ANOVA) was used to test treatment effects of water quality variables (i.e., turbidity, $\mathrm{TP}, \mathrm{NO}_{3}{ }^{-}, \mathrm{NO}_{2}{ }^{-}$, $\mathrm{NH}_{4}{ }^{+}$, chl- $a$ ) and zooplankton abundance measured from individual mesocosms repeatedly (i.e., one to three times weekly) using PROC MIXED (SAS, 2008). Akaike's information criterion for small sample size (AICc; Hurvich \& Tsai, 1989; Burnham \& Anderson, 2002) was used to compare RM ANOVA models with different covariance structures (Littel et al., 2002) for each water quality data set (i.e., turbidity, TP, $\mathrm{NO}_{3}{ }^{-}, \mathrm{NO}_{2}{ }^{-}, \mathrm{NH}_{4}{ }^{+}$, chl- $a$ ) and zooplankton taxa (i.e., rotifers, copepods, cladocerans). In addition to the RM ANOVA, one-way ANOVA was used to compare treatment means within weeks for water quality variables and zooplankton abundance using Tukey's honestly significant difference test for multiple comparisons (Tukey, 1949). Treatment effects of variables measured pre- and post- experiment (i.e., biomass of macrophytes and benthic macroinvertebrates and abundance of benthic macroinvertebrates) were compared individually with oneway ANOVA. Data were natural log-transformed when necessary to meet the assumption of homogeneous variances among treatment groups. All analyses were performed using SAS 9.2 (SAS, 2008) with a type I error rate of 0.05 .

\section{Results}

Turbidity

Mean turbidity increased in the presence of fish treatments and was consistent throughout the course of the experiment (Fig. 1a; Table 1). Turbidity of the common carp and both-species treatments was similar (RM ANOVA; $F_{1,12}=2.3, P=0.15$ ), but differed from that of the control treatment (RM ANOVA; $F_{1,12}=341, P<0.0001 ; F_{1,12}=400, P<0.0001$, respectively). Mean turbidity increased in the bullhead treatment mesocosms relative to the control treatment (RM ANOVA; $F_{1,12}=153, P<0.0001$ ), but was significantly less than that of the common carp treatment (RM ANOVA; $\left.F_{1,12}=37, P<0.0001\right)$ and the both species-treatment $\left(F_{1,12}=58, P<0.0001\right)$.

\section{Nutrient concentrations}

Mean TP concentrations increased in treatments containing fish, and no effect of treatment $\times$ day interaction was evident (Fig. 1b; Table 1; RM ANOVA $\left.F_{21,84}=0.71, P=0.81\right)$. Mean TP concentrations were highest in the both-species treatment and were similar to those of the common carp treatment (RM ANOVA; $F_{1,12}=0.57, P=0.47$ ), but were higher than those of the black bullhead (RM ANOVA; $F_{1,12}=6.4, P=0.027$ ) and control (RM ANOVA; $\left.F_{1,12}=42, P<0.0001\right)$ treatments. Mean concentration of TP for the black bullhead treatment increased relative to the control treatment (RM ANOVA; $\left.F_{1,12}=16, P=0.0019\right)$ and did not differ from that of the common carp treatment (RM ANOVA; $F_{1,12}=$ 3.1, $P=0.10)$. Treatment effects on mean $\mathrm{NO}_{3}{ }^{-}$ concentrations varied with time (Table $1 ; F_{30,120}=$ 4.4, $P<0.0001$ ). Mean $\mathrm{NO}_{3}{ }^{-}$concentrations increased in common carp and both-species treatments compared to the black bullhead and control treatments (Fig. 1c; 


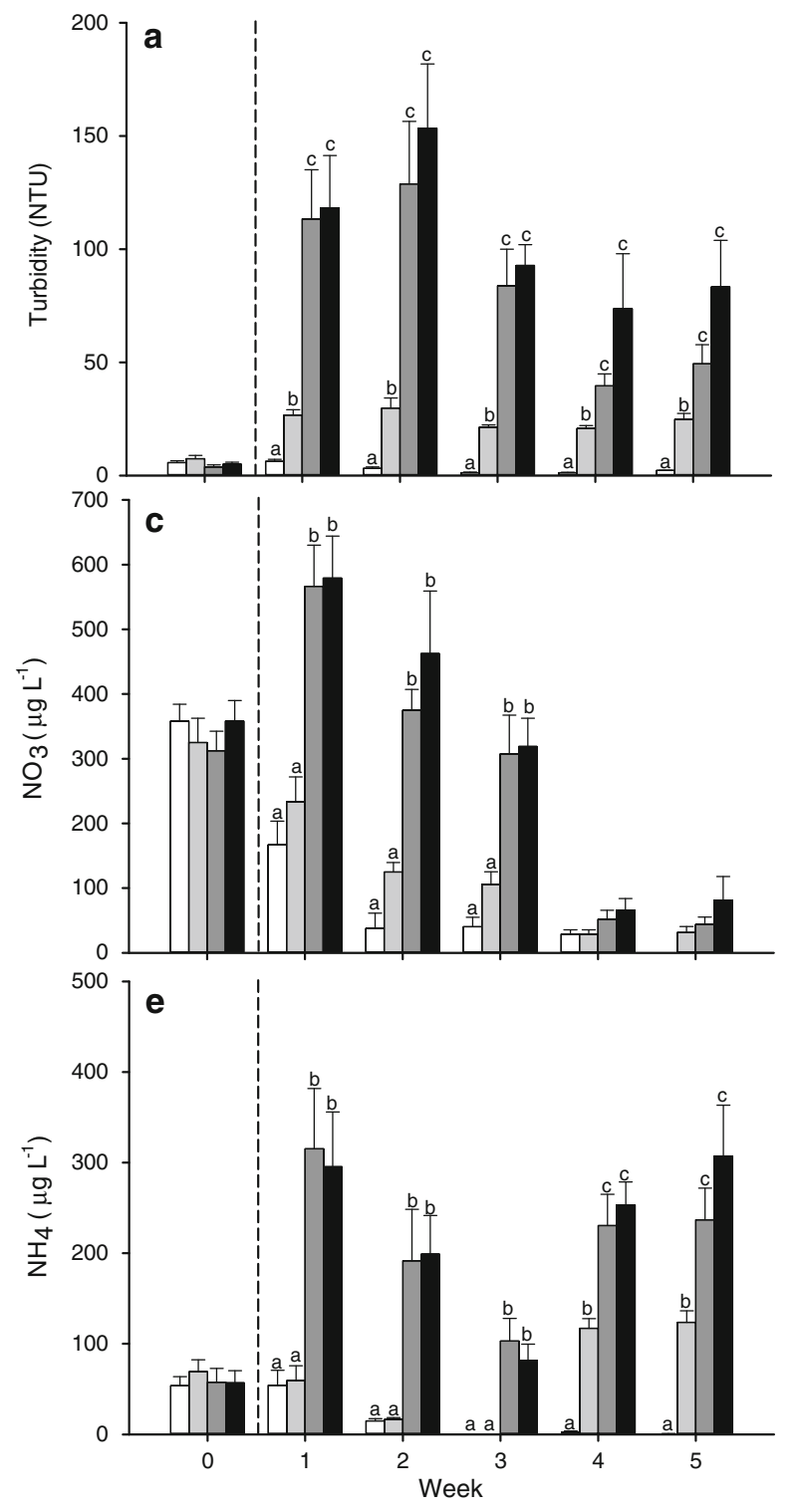

Fig. 1 Turbidity (a), TP (b), $\mathrm{NO}_{3}^{-}(\mathbf{c}), \mathrm{NO}_{2}^{-}$(d), and $\mathrm{NH}_{4}{ }^{+}$ (e), and chl- $a$ (f) (mean \pm SE) from mesocosms over time with no fish (control), and 1,000 $\mathrm{g}$ of biomass of black bullhead (A. melas), common carp (C. carpio), and both species (A. melas + C. carpio). Week-0 values represent samples taken
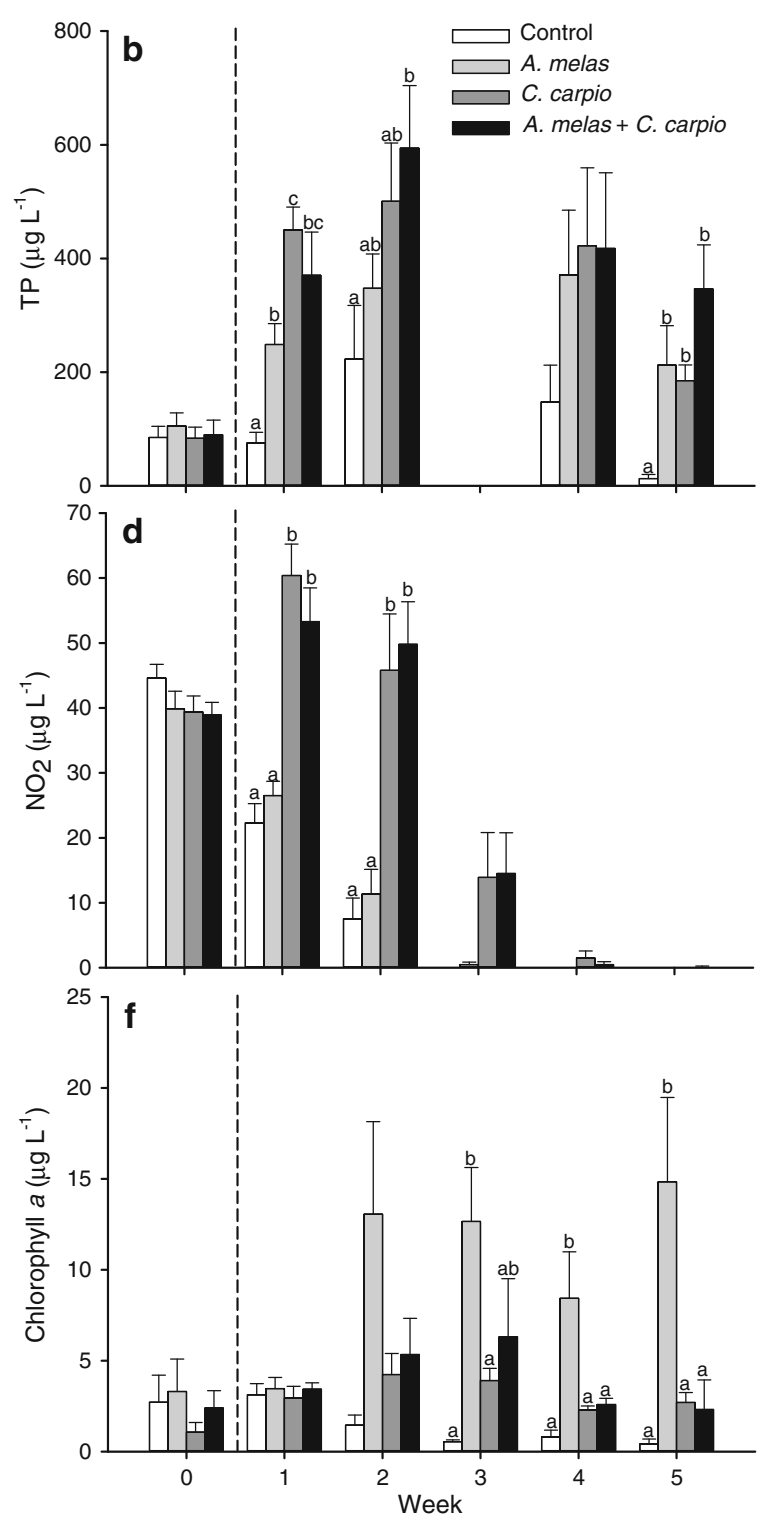

prior to fish stocking (dashed line). Each treatment was replicated four times and values with the same letter were not significantly different $(P<0.05$; one-way ANOVA of $\log$ transformed data) for within week means

common carp and both-species treatments (RM ANOVA; $\left.\quad F_{1,12}=18-39, \quad P \leq 0.001\right)$. Treatment effects on mean $\mathrm{NO}_{2}{ }^{-}$concentrations varied with time (Table 1; treatment $\times$ day interaction; $F_{33,132}=4.0$, $P<0.0001$ ). Mean $\mathrm{NO}_{2}{ }^{-}$concentrations of the bothspecies and common carp treatments were similar (Fig. 1d; RM ANOVA; $F_{1,12}=0.18, P=0.68$ ), while 
Table 1 Summary results of RM ANOVA used to test treatment effects for limnologic variables and zooplankton abundance

\begin{tabular}{|c|c|c|c|c|c|c|c|c|c|}
\hline \multirow[t]{2}{*}{ Variable } & \multicolumn{3}{|l|}{ Treatment } & \multicolumn{3}{|l|}{ Days } & \multicolumn{3}{|c|}{ Treatment $\times$ day } \\
\hline & $\mathrm{df}_{\text {(Num,Den) }}$ & $F$ & $P$ & $\mathrm{df}_{(\text {Num,Den) }}$ & $F$ & $P$ & $\mathrm{df}_{\text {(Num,Den) }}$ & $F$ & $P$ \\
\hline \multicolumn{10}{|l|}{ Limnologic } \\
\hline Turbidity $^{\mathrm{a}}$ & 3,12 & 165 & $<0.0001$ & 11,132 & 5.2 & $<0.0001$ & 33,132 & 1.2 & 0.22 \\
\hline $\mathrm{TP}^{\mathrm{b}}$ & 3,12 & 17 & 0.0001 & 7,84 & 20 & $<0.0001$ & 21,84 & 0.71 & 0.81 \\
\hline Chl- $a^{\mathrm{b}}$ & 3,12 & 30 & $<0.0001$ & 5,60 & 2.3 & 0.060 & 15,60 & 1.8 & 0.056 \\
\hline $\mathrm{NO}_{3}^{-\mathrm{c}}$ & 3,12 & 19 & $<0.0001$ & 10,120 & 55 & $<0.0001$ & 30,120 & 4.4 & $<0.0001$ \\
\hline $\mathrm{NO}_{2}^{-\mathrm{a}}$ & 3,12 & 26 & $<0.0001$ & 11,132 & 46 & $<0.0001$ & 33,132 & 4.0 & $<0.0001$ \\
\hline $\mathrm{NH}_{4}^{+\mathrm{c}}$ & 3,12 & 38 & $<0.0001$ & 10,120 & 5739 & $<0.0001$ & 30,120 & 3153 & $<0.0001$ \\
\hline \multicolumn{10}{|l|}{ Zooplankton } \\
\hline Rotifers $^{\mathrm{a}}$ & 3,12 & 5.7 & 0.012 & 4,48 & 13 & $<0.0001$ & 12,48 & 1.9 & 0.061 \\
\hline Copepods $^{\mathrm{b}}$ & 3,12 & 38 & $<0.0001$ & 4,48 & 2.2 & 0.079 & 12,48 & 1.9 & 0.052 \\
\hline Cladocerans ${ }^{\mathrm{b}}$ & 3,12 & 6.0 & $<0.0001$ & 4,48 & 6.4 & $<0.0001$ & 12,48 & 2.5 & 0.011 \\
\hline
\end{tabular}

Letters indicate the covariance model selected using Akaike's information criterion for small sample size ( ${ }^{a}$ auto regressive,

${ }^{\mathrm{b}}$ compound symmetry, ${ }^{\mathrm{c}}$ unstructured) in the RM ANOVA

TP total phosphorus, Chl- $a$ chlorophyll $a$

greater than those of the control and black bullhead treatments (RM ANOVA; $F_{1,12}=32-45, \quad P \leq$ $0.0001)$. The control and black bullhead mean $\mathrm{NO}_{2}{ }^{-}$ concentrations treatments were similar (RM ANOVA; $\left.F_{1,12}=0.42, P=0.53\right)$. Treatment effects on mean $\mathrm{NH}_{4}{ }^{+}$concentrations varied with time (Table 1; $\left.F_{30,120}=3153, P<0.0001\right)$. Throughout the experiment, mean $\mathrm{NH}_{4}{ }^{+}$concentrations of the both-species and carp treatments were similar (Fig. 1e; RM ANOVA; $\left.\quad F_{1,12}=0.25, \quad P=0.63\right)$ but consistently higher than those of the black bullhead and control treatments (RM ANOVA; $F_{1,12}=34-77, P \leq$ $0.0001)$.

\section{Chlorophyll $a$}

Mean chl- $a$ concentrations increased in the black bullhead treatment (Fig. 1f; Table 1) compared to all other treatments (RM ANOVA; $F_{1,12}=39-77$, $P<0.0001)$ and treatment effects were consistent for the duration of the study (Table 1; treatment $\times$ day interaction; $F_{15,60}=1.8, P=0.056$ ). The mean concentration of chl- $a$ for the both-species treatment was greater than that of the control treatment (RM ANOVA; $\left.F_{1,12}=6.3, P=0.028\right)$ and similar to that of the common carp treatment (RM ANOVA; $F_{1,12}=0.97, P=0.35$ ).
Aquatic macrophytes

Below-substrate macrophyte biomass (i.e., root) was not influenced by experimental treatment (Fig. 2; ANOVA; $\left.F_{3,12}=2.2, P=0.15\right)$. However, mean total macrophyte biomass (i.e., stems, leaves, and roots) differed among treatments (ANOVA; $F_{3,12}=3.6, P=0.045$ ). Mean total macrophyte biomass was lower in the common carp (ANOVA; $F_{3,12}=7.5, P=0.018$ ) and both-species (ANOVA; $F_{3,12}=5.7, P=0.035$ ) treatments relative to the control treatment. Mean macrophyte biomass of the black bullhead treatment was similar to that of the control treatment (ANOVA; $F_{1,12}=0.31, P=0.59$ ), but greater than that of the common carp treatment (ANOVA; $F_{1,12}=4.8$, $P=0.049$ ). Macrophyte biomass of the both-species treatment was similar to that of the common carp treatment (ANOVA; $F_{1,12}=0.13, P=0.73$ ) and marginally similar to that of the black bullhead treatment (ANOVA; $F_{1,12}=3.3, P=0.093$ ).

\section{Zooplankton composition}

Throughout the experiment, zooplankton composition was dominated $(>75 \%$ of total zooplankton abundance) by rotifers represented mostly by Brachinonus and Keratella species. Copepods were the next most abundant taxa sampled $(20.8 \%$ of total zooplankton 


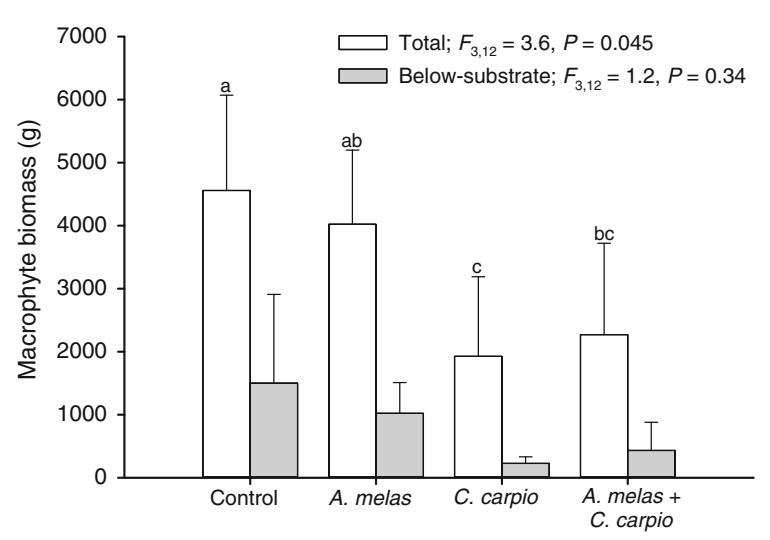

Fig. 2 Post-experiment macrophyte biomass (mean \pm SE) from mesocosms with no fish (control), and 1,000 $\mathrm{g}$ of biomass of black bullhead, common carp, and both species $(n=4$ per treatment). Values with the same letter were not significantly different $(P<0.05$; ANOVA of $\log$ transformed data $)$

abundance) and were predominantly nauplii ( $66.5 \%$ of total copepod abundance) followed by adult cyclopoid and calanoid copepods (25.7 and $7.8 \%$ of total copepod abundance, respectively). Cladocerans comprised the smallest proportion of zooplankton sampled $(<1 \%)$, and were represented by Bosminidae, Chydoridae, Daphniidae, and Sididae species. Mean abundance of rotifers differed among experimental treatments, and treatment effects were consistent across time (Fig. 3a; Table 1; RM ANOVA treatment $\times$ day interaction; $F_{12,48}=1.9, P=0.061$ ). Rotifer abundance of the control treatment was similar to that of the black bullhead treatment (RM ANOVA; $\left.F_{1,12}=5.6, P=0.035\right)$, but marginally similar to that of the both-species treatment (RM ANOVA; $\left.F_{1,12}=3.6, P=0.082\right)$. The common carp treatment had higher abundance of rotifers than the both-species treatment (RM ANOVA; $\left.F_{1,12}=4.8, P=0.048\right)$ and the control treatment (RM ANOVA; $F_{1,12}=17$, $P=0.0015)$, but was similar to that of the black bullhead treatment (RM ANOVA; $F_{1,12}=3.0$, $P=0.11)$. Treatment effects on mean copepod abundance were consistent for the duration of the experiment (Fig. 3b; Table 1; RM ANOVA; $F_{12,48}=1.9$, $P=0.052$ ) and mean copepod abundance was higher in all treatments containing fish relative to the control treatment (RM ANOVA; $F_{1,12}=56-75, P<$ $0.0001)$. Copepod density in the both-species treatment was similar to those in the common carp treatment (RM ANOVA; $\left.F_{1,12}=1.5, \quad P=0.24\right)$ and the black bullhead treatment (RM ANOVA; $\left.F_{1,12}=0.63, P=0.44\right)$. Mean cladoceran abundance varied with time for treatments (Fig. 3c; Table 1; RM ANOVA; $F_{12,48}=2.5, P=0.011$ ). Cladoceran abundance was lowest in the common carp treatment, which was similar to that of the both-species treatment (RM ANOVA; $F_{1,12}=0.06, P=0.82$ ). Cladoceran density was highest in the control treatment and differed from those of the common carp and bothspecies treatments (RM ANOVA; $F_{1,12}=10-12$, $P \leq 0.0078)$. Cladoceran density of the black bullhead treatment was similar to that of the control (RM ANOVA; $\left.F_{1,12}=0.49, P=0.50\right)$.

\section{Benthic macroinvertebrates}

Benthic macroinvertebrate assemblages were dominated by Chironomidae and Oligochaeta, which comprised 60.6 and $48.6 \%$ of the pre- and postexperiment densities, respectively. Pre-experiment total benthic macroinvertebrate abundance did not differ among treatments (Fig. 4a; ANOVA; $F_{3,12}=$ $0.62, P=0.61)$. However, post-experiment mean density was influenced by experimental treatment (ANOVA; $F_{3,12}=6.2, P=0.0087$ ) and was highest for the control treatment, which was similar to that of the black bullhead treatment (ANOVA; $F_{1,12}=0.02$, $P=0.88$ ). Densities of benthic macroinvertebrates in the common carp and both-species treatments were similar (ANOVA; $F_{1,12}=1.7, P=0.22$ ) and were substantially lower than those of the control and black bullhead treatments. Similarly, mean biomass of macroinvertebrates was similar prior to the experiment (Fig. $4 \mathrm{~b}$; ANOVA; $F_{3,12}=1.3, P=0.33$ ), but differed post-experiment (ANOVA; $F_{3,12}=4.3$, $P=0.028$ ). Biomass of macroinvertebrates was highest in the black bullhead treatment and was similar to that of the control treatment (ANOVA; $F_{1,12}=0.59$, $P=0.46)$, but higher than that of the common carp (ANOVA; $F_{1,12}=9.5, P=0.0094$ ) and those of the both-species (ANOVA; $F_{1,12}=6.7, P=0.023$ ) treatments. Macroinvertebrate biomass of the control treatment was greater than that of the common carp treatment (ANOVA; $F_{1,12}=5.4, P=0.039$ ). In addition, the biomass of macroinvertebrates was similar (ANOVA; $F_{1,12}=0.24, P=0.63$ ) for the common carp and both-species treatments. 


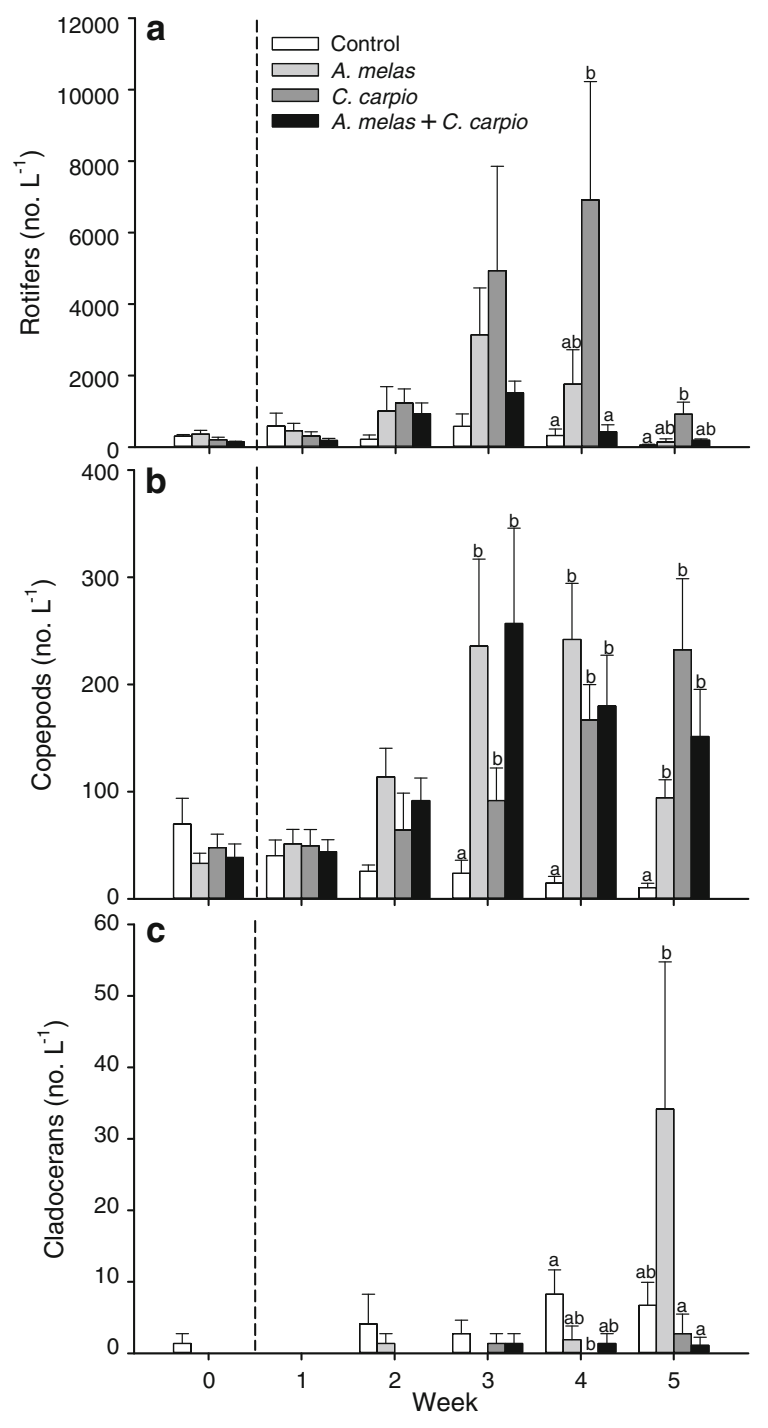

Fig. 3 Weekly zooplankton density (mean \pm SE) from mesocosms over time with no fish (control), and 1,000 g of biomass of black bullhead, common carp, and both species ( $n=4$ per treatment). Week-0 values represent samples taken prior to fish stocking (dashed line). The $P$ value represents the significance of the treatment effect from the RM ANOVA. Values with the same letter were not significantly different $(P<0.05$; ANOVA of $\log$ transformed data) for within week means

\section{Discussion}

Decreased water quality (e.g., increased turbidity, increased $\mathrm{NO}_{3}{ }^{-}, \mathrm{NO}_{2}{ }^{-}, \mathrm{NH}_{4}{ }^{+}$, and $\mathrm{TP}$ concentrations), reduced macrophyte biomass, and reduced benthic invertebrate abundance and biomass were consistently observed in treatments containing common carp. Additive effects of common carp and black
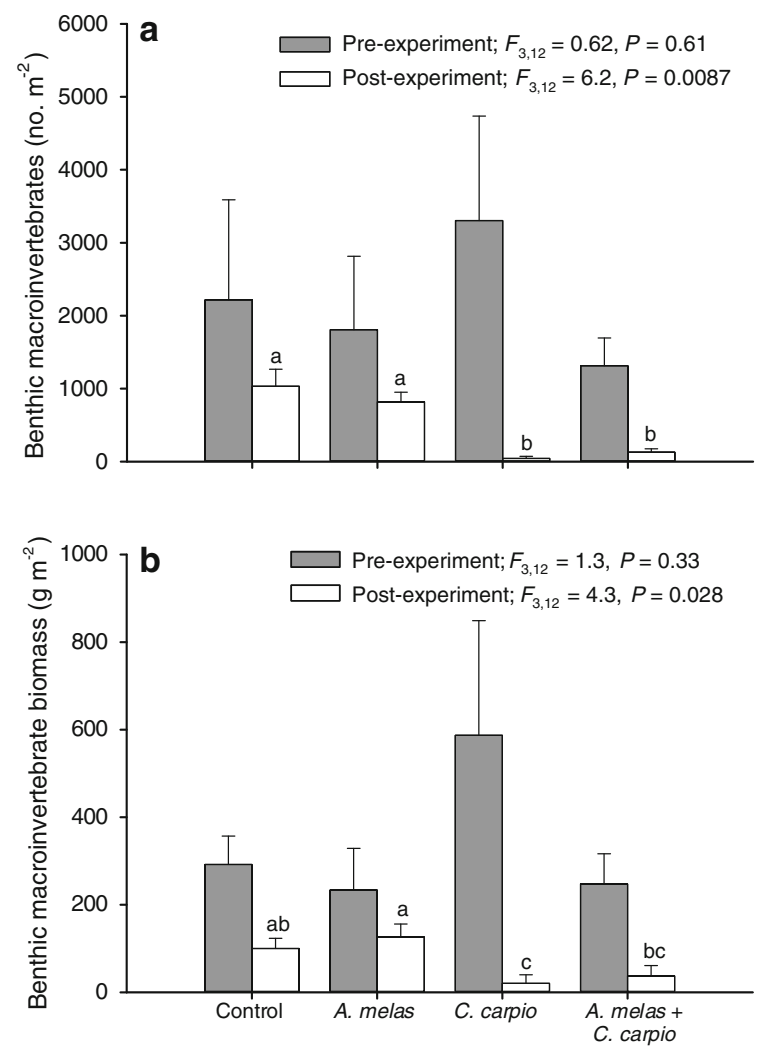

Fig. 4 Pre- and post-experiment benthic macroinvertebrate density (a) and biomass (b) (mean \pm SE) from mesocosms with no fish (control), and 1,000 $\mathrm{g}$ of biomass of black bullhead, common carp, and both species ( $n=4$ per treatment). Values with the same letter were not significantly different $(P<0.05$; ANOVA of log transformed data)

bullhead were not observed in that results from the treatment with both species were consistently similar to those of the common carp treatment for nearly all of the abiotic and biotic responses measured. However, intermediate increases in turbidity and TP concentrations occurred for the black bullhead treatment relative to control conditions and those containing common carp and likely resulted in elevated chl- $a$ concentrations. Therefore, the ecological impacts of black bullhead relative to common carp do not seem to warrant their target for removal during the restoration and management of aquatic ecosystems. Furthermore, the results of our experimental study corroborate other research that has evaluated the effects of native fishes that occupy a similar ecological niche to that of common carp (e.g., brown bullhead, channel catfish: Cline et al., 1994; Batzer, 1998; Parkos et al., 2003) and are likely the result of differing mechanisms for 
disturbance between common carp and black bullhead.

Like many benthic fish species, common carp and black bullhead possess adaptations that are beneficial to locating prey in benthic habitats. However, differences in the observed responses of abiotic and biotic variables for treatments containing black bullhead and common carp were possibly attributed to morphologic and behavioral differences between the species associated with feeding. Specifically, common carp rely on the suction of benthic substrates with a protrusile mouth to filter prey from large volumes of water and inorganic particles with their gill rakers (Sibbing, 1988). In contrast, black bullhead have a terminal mouth structure, and similar to many catfish species (Siluriformes), rely heavily on gustatory organs (i.e., taste buds) that are present on the epidermis of the body and barbels to locate prey (Parker, 1910; Hara, 1994). Therefore, common carp are less discriminate feeders than black bullhead and have a greater potential to physically suspend benthic sediments, thereby increasing available nutrients and contributing to altered physical states of aquatic ecosystems. The larger adult size of common carp is also crucial to the capability of uprooting aquatic macrophytes while actively foraging for prey. Black bullhead did not alter rooted macrophyte biomass in the experiment and therefore should not be considered a nuisance to clearwater, macrophyte-dominated states of shallow aquatic systems. Thus, our comparison of two benthic omnivores demonstrated dissimilar ecosystem effects that were likely the result of differences in morphology and feeding behavior.

Common carp can increase nutrient concentrations in the water through excretion, resuspension of sediments into the water column, or the release of nutrients caused by the destruction and resulting decay of aquatic macrophytes (Carpenter \& Lodge, 1986; Qin \& Threlkeld, 1990; Breukelaar et al., 1994; Chumchal \& Drenner, 2004). As such, numerous experimental and observational studies have demonstrated increased nutrient concentrations associated with increased common carp biomass (e.g., Lougheed et al., 1998; Chumchal et al., 2005; Matsuzaki et al., 2007; Roozen et al., 2007). In the present study, treatments containing common carp consistently increased $\mathrm{NO}_{3}{ }^{-}, \mathrm{NO}_{2}{ }^{-}$, and $\mathrm{NH}_{4}{ }^{+}$concentrations compared to control conditions. Black bullhead, however, had no effect on increased $\mathrm{NO}_{3}{ }^{-}, \mathrm{NO}_{2}{ }^{-}$, and $\mathrm{NH}_{4}{ }^{+}$concentrations intermediate to those of control and common carp treatments for the duration of the experiment. The observed patterns of nutrient concentrations in the control treatment supported the effects caused by common carp activity in both treatments containing common carp. Specifically, concentrations of nitrogen components (i.e., $\mathrm{NO}_{3}{ }^{-}$, $\mathrm{NO}_{2}{ }^{-}, \mathrm{NH}_{4}{ }^{+}$) consistently decreased over time in the control treatment, suggesting uptake by aquatic autotrophs (i.e., macrophytes, phytoplankton) and denitrification. Therefore, increased nitrogen concentrations in treatments containing common carp may have been attributed to limited macrophyte uptake resulting from uprooting and eventual release of sequestered nutrients by decaying vegetation (Carpenter \& Lodge, 1986). Despite decreases in $\mathrm{NH}_{4}^{+}$in weeks one through three, $\mathrm{NH}_{4}{ }^{+}$concentrations increased in all treatments containing fish during weeks four and five. This increase was likely the result of increased $\mathrm{NH}_{3}$ through excretion in closed mesocosms stocked with high biomass of fish. Pre-experiment TP concentrations in mesocosms were eutrophic (approximately $90 \mu \mathrm{g} \mathrm{l}^{-1}$ ), which was similar to those reported by Parkos et al. (2003). Parkos et al. (2003) observed intermediate increases in TP concentrations associated with channel catfish and suggested that benthic fishes that disturb the sediment less than common carp may increase phosphorus primarily through excretion. Similar to Parkos et al. (2003), we observed intermediate increases in TP associated with black bullhead compared to the control and treatments containing common carp (i.e., common carp and both-species treatments). However, we do not know if increased TP in black bullhead treatments over control conditions in our experiment was the result of the physical disruption of sediments or excretion.

Increased chl- $a$ concentrations were not observed in treatments containing common carp. This was in contrast to other studies that have found that common carp can increase phytoplankton abundance (using chl- $a$ concentrations as a surrogate for phytoplankton densities; reviewed by Chumchal \& Drenner, 2004; Chumchal et al., 2005; Matsuzaki et al., 2009). Similar to our results, Lougheed et al. (1998) did not observe a significant relationship between chl- $a$ and common carp biomass despite increases in $\mathrm{TP}$ and $\mathrm{NH}_{4}$. In our study, an increase in mean chl- $a$ concentration for the black bullhead treatment was observed approximately 1 week after stocking and then persisted throughout 
the experiment. Low chl- $a$ concentrations in treatments containing common carp were possibly caused by light limitation resulting from increased turbidity; thereby negating the potential effects of increased nutrients. Therefore, moderate increases in TP coupled with light availability in the black bullhead treatment may have resulted in increased phytoplankton production and subsequent chl- $a$ concentrations, while also sustaining macrophyte occurrence.

The indirect effects of benthivorous species on zooplankton are complex and not well understood. As such, studies of adult common carp-induced effects on zooplankton densities have commonly reported mixed results for various taxa. For instance, common carp presence has caused a decrease or no change in the density of zooplankton (Qin \& Threlkeld, 1990; Lougheed et al., 1998; Sidorkewicj et al., 1998), whereas increased density of copepods (Parkos et al., 2003; Matsuzaki et al., 2009) and rotifers (Chumchal et al., 2005; Matsuzaki et al., 2007; Matsuzaki et al., 2009) have been reported. Despite differences in the chl- $a$ concentrations (i.e., phytoplankton abundance), increased copepod density was observed in all treatments containing fish. Increases in available nutrients (e.g., TP) can often increase phytoplankton abundance and biomass, which can indirectly increase abundance of zooplankton grazers (e.g., calanoid copepods). In our study, increased density of copepods in the black bullhead treatments may have resulted from increased phytoplankton abundance. In contrast, Parkos et al. (2003) attributed decreased copepod abundance in carp enclosures to reduced invertebrate predators (e.g., odonates; Burks et al., 2001). Increased abundance of rotifers has commonly been associated with increased biomass of common carp (Chumchal et al., 2005; Matsuzaki et al., 2007; Matsuzaki et al., 2009). We did not observe consistent patterns of rotifer density among experimental treatments, which was comparable to previous studies (Lougheed et al., 1998; Roozen et al., 2007); however, our sampling used $80 \mu \mathrm{m}$ mesh and may have underrepresented the density of smaller rotifers (Chick et al., 2010). Despite potential underrepresentation of very small rotifers, the relative comparison of treatments using the same methods should remain valid for rotifers susceptible to sampling with $80 \mu \mathrm{m}$ mesh. In contrast to Roozen et al. (2007), we observed increased cladoceran abundance in the absence of common carp. This may have been attributed to decreased predation by invertebrate predators (Burks et al., 2001; Parkos et al., 2003) and increased biomass of macrophytes (e.g., refugia; Burks et al., 2001) in treatments not containing common carp.

Common carp can inhibit macrophyte growth directly through physical uprooting and consumption (King \& Hunt, 1967; Crivelli, 1983; Sidorkewicj et al., 1996; Haas et al., 2007) or indirectly through shading caused by increased turbidity (Sidorkewicj et al., 1996; Lougheed et al., 1998; Zambrano \& Hinojosa, 1999; Matsuzaki et al., 2007). Changes in aquatic macrophytes and other water quality characteristics due to invasive common carp have been associated with decreased biodiversity (e.g., water birds: Haas et al., 2007; Bajer et al., 2009). In addition, larger common carp can be more destructive to macrophytes than smaller individuals (Crivelli, 1983; Sidorkewicj et al., 1998; Kloskowski, 2011). Therefore, results from our study may not be directly comparable among treatments (i.e., differences in sizes of common carp and black bullhead) despite equal biomass stockings. However, the smaller average adult size of black bullhead (165-229 mm TL; Becker, 1983) would suggest a limited effect on uprooting and destruction of macrophytes relative to common carp (406-447 mm TL; Becker, 1983) in natural systems. In addition, indirect effects such as sediment resuspension can be particularly inhibitive to macrophyte growth. In a study evaluating the relationship between water clarity and macrophyte diversity of shallow wetlands, Lougheed et al. (1998) observed a speciesrichness threshold of 20 NTU for macrophytes. Systems with turbidity above 20 NTU consistently contained fewer than five submerged macrophyte species that were tolerant of high turbidity (e.g., sago pond weed Potamogeton pectinatus), whereas less turbid systems harbored a diverse macrophyte assemblage (up to 15 species). Similar to results reported by Braig and Johnson (2003), we did not observe increased surface turbidity above approximately 20 NTU in the black bullhead treatment, despite greater biomass densities in our experiment $\left(4,000 \mathrm{~kg} \mathrm{ha}^{-1}\right)$ compared to their study $\left(2,438 \mathrm{~kg} \mathrm{ha}^{-1}\right)$. In addition, no difference in macrophyte biomass was observed between bullhead and control treatments. It should be noted that our experiment evaluated the impacts of both species on established macrophytes, and further research is required to understand how native benthic omnivorous fish species impact the emergence of 
macrophytes. Therefore, our results suggest that even at high density, the potential indirect and direct effects of black bullhead activity on established aquatic macrophytes do not appear to be ecologically significant compared to those observed for common carp.

Although the primary objective of our study was to experimentally compare the relative influence of two benthic fish species, the high biomass of fish and small size of the mesocosms are potential limitations of our study that warrant further consideration before making inferences to natural systems. The biomass of fish used in our study was limited by the size of common carp that could be collected (i.e., approximately $500 \mathrm{~g}$ ), the size of the mesocosms, and the study design (i.e., equal fish biomass treatments). Whereas biomasses of common carp have been reported as high as $3,144 \mathrm{~kg} \mathrm{ha}^{-1}$ (Driver et al., 1997) and densities of 7,700 and 3,616 no. ha ${ }^{-1}$ for carp $<100$ and $>100 \mathrm{~mm}$ in Australia, respectively (Reid \& Harris, 1997), biomasses of common carp in lentic ecosystems of North America are generally less than $500 \mathrm{~kg} \mathrm{ha}^{-1}$ (Crivelli, 1983; Bajer et al., 2009). In addition, our use of high biomass $\left(4,098.0 \pm 75.3 \mathrm{~kg} \mathrm{ha}^{-1}\right)$ may not reflect natural aggregations of fishes during foraging or spawning because of the influence of small mesocosms. However, common carp generally inhabit the littoral areas of lentic systems (Swee \& McCrimmon, 1966; Penne \& Pierce, 2008; Bajer et al., 2010) where macrophytes are present and whole-lake extrapolations of biomass may serve as a conservative estimate for species strongly associated with littoral areas.

Although the conditions of our study (e.g., baseline water quality, zooplankton, and macroinvertebrate assemblage structure) are reflective of eutrophic conditions, they are likely representative of the majority of aquatic systems (i.e., shallow lakes, small impoundments) in which common carps induce catastrophic changes (i.e., stable state shifts; Jackson et al., 2010; Weber \& Brown, 2011). In shallow aquatic ecosystems where black bullhead are native, the species may provide a practical monitoring tool for environmental assessments. For example, high susceptibly to sampling methods that are commonly used to monitor lentic fish assemblages (Brown et al., 1999; Hanchin et al., 2002b; Cucherousset et al., 2006) and population characteristic responses (i.e., increased abundance, decreased mortality, increased recruitment, increased growth) to decreases in environmental quality (e.g., Brown et al., 1999; Phelps et al., 2005; Mork et al., 2009) are characteristics that make black bullhead a potentially useful indicator of ecological conditions of aquatic systems. In summary, results of the current study imply that black bullhead do not strongly contribute to the deterioration of water quality conditions and may be viewed as an ecological indicator, rather than a target of management measures where the species is native.

Acknowledgments The authors thank S. Bisping, L. Brown, R. Clayton, M. Dzul, C. Hinz, N. Howell, N. Johnson, M. Mork, J. Morris, C. Smith, and J. Spiegel for their assistance with the project. The authors also thank M. Colvin, C. Paukert, S. Diehl, K. Kovalenko, and five anonymous reviewers for providing useful comments and advice on previous manuscript versions. This project was supported, in part, by Iowa State University, Iowa Department of Natural Resources, and Idaho Cooperative Fish and Wildlife Research Unit. The Unit is jointly sponsored by the University of Idaho, U.S. Geological Survey, Idaho Department of Fish and Game, and Wildlife Management Institute. The use of trade, firm, or product names is for descriptive purposes only and does not imply endorsement by the U.S. Government.

\section{References}

APHA, 2005. Standard Methods for the Examination of Water and Wastewater, 21st ed. American Public Health Association, Washington, DC.

Bajer, P. G. \& P. W. Sorensen, 2010. Recruitment and abundance of an invasive fish, the common carp, is driven by its propensity to invade and reproduce in basins that experience winter-time hypoxia in interconnected lakes. Biological Invasions 12: 1101-1112.

Bajer, P. G., G. Sullivan \& P. W. Sorensen, 2009. Effects of a rapidly increasing population of common carp on vegetative cover and waterfowl in a recently restored Midwestern shallow lake. Hydrobiologia 632: 235-245.

Bajer, P. G., H. Lim, M. J. Travaline, B. D. Miller \& P. W. Sorensen, 2010. Cognitive aspects of food searching behavior in free-ranging wild Common Carp. Environmental Biology of Fishes 88: 295-300.

Batzer, D. P., 1998. Trophic interactions among detritus, benthic midges, and predatory fish in a freshwater marsh. Ecology 79: $1688-1698$.

Becker, G. C., 1983. Fishes of Wisconsin. The University of Wisconsin Press, Madison.

Braig, E. C. \& D. L. Johnson, 2003. Impact of black bullhead (Ameiurus melas) on turbidity in a diked wetland. Hydrobiologia 490: 11-21.

Breukelaar, A. W., E. Lammens, J. Breteler \& I. Tatrai, 1994. Effects of benthivorous bream (Abramis brama) and carp (Cyprinus carpio) on sediment resuspension and concentrations of nutrients and chlorophyll- $a$. Freshwater Biology 32: 113-121. 
Brown, M. L., D. W. Willis \& B. G. Blackwell, 1999. Physicochemical and biological influences on black bullhead populations in eastern South Dakota glacial lakes. Journal of Freshwater Ecology 14: 47-60.

Burks, R. L., E. Jeppesen \& D. M. Lodge, 2001. Pelagic prey and benthic predators: impact of odonate predation on Daphnia. Journal of the North American Benthological Society 20: 615-628.

Burnham, K. P. \& D. R. Anderson, 2002. Model Selection and Multimodel Inference: A Practical Information-Theoretic Approach, 2nd ed. Springer, New York.

Cahn, A. R., 1929. The effect of carp on a small lake-the carp as a dominant. Ecology 10: 271-274.

Carlander, K. D. \& R. B. Moorman, 1956. Standing crop of fish in Iowa ponds. Proceedings of the Iowa Academy of Science 63: 659-668.

Carpenter, S. R. \& D. M. Lodge, 1986. Effects of submersed macrophytes on ecosystem processes. Aquatic Botany 26: 341-370.

Chick, J. H., A. P. Levchuk, K. A. Medley \& J. H. Havel, 2010. Underestimation of rotifer abundance a much greater problem than previously appreciated. Limnology and Oceanography-Methods 8: 79-87.

Chumchal, M. M. \& R. W. Drenner, 2004. Interrelationships between phosphorus loading and common carp in the regulation of phytoplankton biomass. Archiv Fur Hydrobiologie 161: 147-158.

Chumchal, M. M., W. H. Nowlin \& R. W. Drenner, 2005. Biomass-dependent effects of common carp on water quality in shallow ponds. Hydrobiologia 545: 271-277.

Cline, J. M., T. L. East \& S. T. Threlkeld, 1994. Fish interactions with the sediment-water interface. Hydrobiologia 275: 301-311.

Crivelli, A. J., 1983. The destruction of aquatic vegetation by carp-a comparison between southern France and the United States. Hydrobiologia 106: 37-41.

Cucherousset, J., J. M. Paillisson \& A. Carpentier, 2006. Is mass removal an efficient measure to regulate the North American catfish Ameiurus melas outside of its native range? Journal of Freshwater Ecology 21: 699-704.

Driver, P. D., J. H. Harris, R. H. Norris \& G. P. Closs, 1997. The role of the natural environment and human impacts in determining biomass densities of common carp in New South Wales rivers. In Harris, J. H. \& P. C. Gehrke (eds), Fish and Rivers in Stress: The NSW Rivers Survey. NSW Fisheries Office of Conservation and the Cooperative Research Centre for Freshwater Ecology, Cronulla: 298.

Egertson, C. J. \& J. A. Downing, 2004. Relationship of fish catch and composition to water quality in a suite of agriculturally eutrophic lakes. Canadian Journal of Fisheries and Aquatic Sciences 61: 1784-1796.

Haas, K., U. Kohler, S. Diehl, P. Kohler, S. Dietrich, S. Holler, A. Jaensch, M. Niedermaier \& J. Vilsmeier, 2007. Influence of fish on habitat choice of water birds: a whole system experiment. Ecology 88: 2915-2925.

Hanchin, P. A., D. W. Willis \& M. J. Hubers, 2002a. Black bullhead growth in South Dakota waters: limnological and community influences. Journal of Freshwater Ecology 17: $65-73$.

Hanchin, P. A., D. W. Willis \& T. R. St Sauver, 2002b. Comparison of concurrent trap-net and gill-net samples for black bullheads. Journal of Freshwater Ecology 17: 233-237.

Hara, T. J., 1994. The diversity of chemical-stimulation in fish olfaction and gustation. Reviews in Fish Biology and Fisheries 4: 1-35.

Hurvich, C. M. \& C. L. Tsai, 1989. Regression and time-series model selection in small samples. Biometrika 76: 297-307.

Jackson, Z. J., M. C. Quist, J. A. Downing \& J. G. Larscheid, 2010. Common carp (Cyprinus carpio), sport fishes, and water quality: ecological thresholds in agriculturally eutrophic lakes. Lake and Reservoir Management 26: $14-22$.

King, D. R. \& G. S. Hunt, 1967. Effect of carp on vegetation in a Lake Erie Marsh. Journal of Wildlife Management 31: 181-188.

Kloskowski, J., 2011. Impact of common carp Cyprinus carpio on aquatic communities: direct trophic effects versus habitat deterioration. Fundamental and Applied Limnology 178: 245-255.

Kulhanek, S. A., A. Ricciardi \& B. Leung, 2011. Is invasion history a useful tool for predicting the impacts of the world's worst aquatic invasive species? Ecological Applications 21: 189-202.

Lee, D. S., C. R. Gilbert, C. H. Hocutt, R. E. Jenkins, D. E. McAllister \& J. R. Stauffer, 1980. Atlas of North American Freshwater Fishes. North Carolina State Museum of Natural History, Raleigh.

Littel, R. C., W. W. Stroup \& R. J. Freund, 2002. SAS for Linear Models. SAS Institute Inc., Cary.

Lougheed, V. L., B. Crosbie \& P. Chow-Fraser, 1998. Predictions on the effect of common carp (Cyprinus carpio) exclusion on water quality, zooplankton, and submergent macrophytes in a Great Lakes wetland. Canadian Journal of Fisheries and Aquatic Sciences 55: 1189-1197.

Matsuzaki, S. S., N. Usio, N. Takamura \& I. Washitani, 2007. Effects of common carp on nutrient dynamics and littoral community composition: roles of excretion and bioturbation. Fundamental and Applied Limnology 168: 27-38.

Matsuzaki, S. S., N. Usio, N. Takamura \& I. Washitani, 2009. Contrasting impacts of invasive engineers on freshwater ecosystems: an experiment and meta-analysis. Oecologia 158: 673-686.

Miller, S. A. \& T. A. Crowl, 2006. Effects of common carp (Cyprinus carpio) on macrophytes and invertebrate communities in a shallow lake. Freshwater Biology 51: 85-94.

Mork, M. D., S. M. Bisping, J. R. Fischer \& M. C. Quist, 2009. Population characteristics of black bullhead (Ameiurus melas) in Iowa natural lakes. Journal of Freshwater Ecology 24: 635-644.

Parker, G. H., 1910. Olfactory reactions in fishes. Journal of Experimental Zoology 8: 535-542.

Parkos, J. J., V. J. Santucci \& D. H. Wahl, 2003. Effects of adult common carp (Cyprinus carpio) on multiple trophic levels in shallow mesocosms. Canadian Journal of Fisheries and Aquatic Sciences 60: 182-192.

Penne, C. R. \& C. L. Pierce, 2008. Seasonal distribution, aggregation, and habitat selection of common carp in Clear Lake, Iowa. Transactions of the American Fisheries Society 137 : 1050-1062.

Phelps, Q. E., M. J. Ward, C. P. Paukert, S. R. Chipps \& D. W. Willis, 2005. Biotic and abiotic correlates with black 
bullhead population characteristics in Nebraska Sandhill Lakes. Journal of Freshwater Ecology 20: 295-302.

Qin, J. G. \& S. T. Threlkeld, 1990. Experimental comparison of the effects of benthivorous fish and planktivorous fish on plankton community structure. Archiv Fur Hydrobiologie 119: 121-141.

Reid, D. D. \& J. H. Harris, 1997. Estimation of total abundance of fish populations: the calibration experiments. In Harris, J. H. \& P. C. Gehrke (eds), Fish and Rivers in Stress: The NSW Rivers Survey. NSW Fisheries Office of Conservation and the Cooperative Research Centre for Freshwater Ecology, Cronulla: 298.

Roozen, F., M. Lurling, H. Vlek, E. Kraan, B. W. Ibelings \& M. Scheffer, 2007. Resuspension of algal cells by benthivorous fish boosts phytoplankton biomass and alters community structure in shallow lakes. Freshwater Biology 52: 977-987.

SAS, 2008. Version 9.2, Cary, NC.

Scheffer, M., S. H. Hosper, M. L. Meijer, B. Moss \& E. Jeppesen, 1993. Alternative equilibria in shallow lakes. Trends in Ecology \& Evolution 8: 275-279.

Schrage, L. J. \& J. A. Downing, 2004. Pathways of increased water clarity after fish removal from Ventura Marsh; a shallow, eutrophic wetland. Hydrobiologia 511: 215-231.

Shapiro, J. \& D. I. Wright, 1984. Lake restoration by biomanipulation: round Lake, Minnesota, the first two years. Freshwater Biology 14: 371-383.

Sibbing, F., 1988. Specializations and limitations in the utilization of food resources by the carp, Cyprinus carpio: a study of oral food processing. Environmental Biology of Fishes 22: 161-178.

Sidorkewicj, N. S., A. C. L. Cazorla \& O. A. Fernandez, 1996. The interaction between (Cyprinus carpio L.) and
(Potamogeton pectinatus L.) under aquarium conditions. Hydrobiologia 340: 271-275.

Sidorkewicj, N. S., A. C. L. Cazorla, K. J. Murphy, M. R. Sabbatini, O. A. Fernandez \& J. C. J. Domaniewski, 1998. Interaction of common carp with aquatic weeds in Argentine drainage channels. Journal of Aquatic Plant Management 36: 5-10.

Swee, U. B. \& H. R. McCrimmon, 1966. Reproductive biology of carp (Cyprinus carpio L.) in lake St. Lawrence, Ontario. Transactions of the American Fisheries Society 95: 372-380.

Tukey, J. W., 1949. Comparing individual means in the analysis of variance. Biometrics 5: 99-114.

Wahl, D. H., M. D. Wolfe, V. J. Santucci \& J. A. Freedman, 2011. Invasive carp and prey community composition disrupt trophic cascades in eutrophic ponds. Hydrobiologia 678: 49-63.

Weber, M. J. \& M. L. Brown, 2009. Effects of common carp on aquatic ecosystems 80 years after "carp as a dominant": ecological insights for fisheries management. Reviews in Fisheries Science 17: 524-537.

Weber, M. J. \& M. L. Brown, 2011. Relationships among invasive common carp, native fishes and physicochemical characteristics in upper Midwest (USA) lakes. Ecology of Freshwater Fish 20: 270-278.

Zambrano, L. \& D. Hinojosa, 1999. Direct and indirect effects of carp (Cyprinus carpio L.) on macrophyte and benthic communities in experimental shallow ponds in central Mexico. Hydrobiologia 408: 131-138.

Zambrano, L., M. Scheffer \& M. Martinez-Ramos, 2001. Catastrophic response of lakes to benthivorous fish introduction. Oikos 94: 344-350. 